\title{
The chemical forms of mercury in blue marlin billfish: Implications for human exposure
}

Alain Manceau ${ }^{1, *}$, Sabine Azemard ${ }^{2}$, Laetitia Hédouin ${ }^{3,4}$, Emilya Vassileva $^{2}$, David Lecchini ${ }^{3,4}$,

Cécile Fauvelot ${ }^{3,5,6}$, Peter W. Swarzenski ${ }^{2}$, Pieter Glatzel ${ }^{7}$, Paco Bustamante ${ }^{8}$ and Marc Metian ${ }^{2, *}$

${ }^{1}$ Université Grenoble Alpes, CNRS, ISTerre, F-38000 Grenoble, France

${ }^{2}$ International Atomic Energy Agency (IAEA), Environment Laboratories, MC-98000

Principality of Monaco, Monaco

${ }^{3}$ Université de Perpignan, Laboratoire d'Excellence CORAIL, F-66100 Perpignan, France

${ }^{4}$ PSL Université Paris, EPHE-UPVD-CNRS, CRIOBE, F-98729 Moorea, French Polynesia

${ }^{5}$ IRD, Université de la Réunion, CNRS, IFREMER, Université de la Nouvelle-Calédonie, ENTROPIE, F-06230 Villefranche-sur-Mer, France

${ }^{6}$ Sorbonne Université, CNRS, Laboratoire d'Océanographie de Villefranche, F-06230 Villefranche-sur-Mer, France

${ }^{7}$ European Synchrotron Radiation Facility (ESRF), F-38000, Grenoble, France

${ }^{8}$ La Rochelle Université, CNRS, Littoral Environnement et Sociétés (LIENSs), F-17000 La Rochelle, France

*Corresponding Authors: alain.manceau@univ-grenoble-alpes.fr; m.metian@iaea.org

ABSTRACT. Although fish is an important source of nutrients, including some of the healthiest proteins, long-chain fatty acid, and essential selenium, species at the top of the food chain frequently contain high amounts of toxic mercury $(\mathrm{Hg})$. The Provisional Tolerable Weekly Intake (PTWI) of $\mathrm{Hg}$ from fish consumption is calculated from the total concentration of $\mathrm{Hg}$ and assuming that all $\mathrm{Hg}$ is speciated as organic methylmercury ( $\mathrm{MeHg}$ ). Using high energy- 
resolution X-ray absorption near edge structure spectroscopy, we show that blue marlin (Makaira sp.), a common top predator consumed by humans, contains elevated concentrations of inorganic $\mathrm{Hg}$ (II) complexed as $57 \pm 10 \%$ Hg-tetraselenolate $\left(\mathrm{Hg}(\mathrm{Sec})_{4}\right)$ and $43 \pm 10 \%$ tiemannite $(\mathrm{HgSe})$. The stable $\mathrm{Hg}$-Se bond likely attenuates the bioavailability of $\mathrm{Hg}$ and counteracts some of its health hazards to consumers. Thus, monitoring the concentration of $\mathrm{MeHg}$, rather than total $\mathrm{Hg}$, in top predators such as marlin would provide a more robust measure of $\mathrm{Hg}$ exposure and may be sufficient for food safety controls. The bonding of $\mathrm{Hg}$ to four selenocysteine ( $\mathrm{Sec}$ ) residues in the $\mathrm{Hg}(\mathrm{Sec})_{4}$ complex severely depletes the stock of bioavailable Se, and quantification shows that blue marlin is not a chief source of dietary Se essential to selenoenzyme synthesis and activity.

\section{INTRODUCTION}

Eating piscivore marine fish warrants caution. ${ }^{1}$ Whereas seafood is the main source of essential selenium (Se) to proper brain function and to developing spermatozoa, ${ }^{2-4}$ top predators can contain toxic concentrations of mercury $(\mathrm{Hg}) .{ }^{5-7}$ Marlin, a billfish consumed by large segments of the Indo-Pacific tropical and subtropical populations and those from the west Atlantic coast, commonly contains several $\mathrm{mg} \mathrm{Hg} / \mathrm{kg}$ wet weight $(\mathrm{ww})^{8-14}$ that exceed the maximum level of 0.5-1.0 mg/kg ww established by the US Environmental Protection Agency, the US Food and Drug Administration (2017), and Health Canada (2014). The Joint FAO/WHO Expert Committee on Food Additives (JECFA) set a provisional tolerable weekly intake (PTWI) of $1.3 \mu \mathrm{g} \mathrm{Hg} / \mathrm{kg}$ body weight (bw) for the organic methylmercury form ( $\mathrm{MeHg}),{ }^{15}$ and $4.0 \mu \mathrm{g} \mathrm{Hg} / \mathrm{kg}$ bw for the inorganic mercuric form $(\mathrm{Hg}(\mathrm{II})) .{ }^{16,17} \mathrm{MeHg}$ is much more extensively and rapidly absorbed than $\mathrm{Hg}$ (II) in the gastrointestinal track, ${ }^{18}$ which is why organic and inorganic $\mathrm{Hg}$ have different PTWI values. It is the first guideline value of $1.3 \mu \mathrm{g} \mathrm{Hg} / \mathrm{kg}$ bw that is usually considered, as nearly all of the $\mathrm{Hg}(>\sim 90 \%)$ generally occurs as $\mathrm{MeHg}$ in muscle of piscivores. ${ }^{19-22}$

Blue marlin (Makaira sp.) is known to accumulate $\mathrm{Hg}$ predominantly in inorganic $\mathrm{Hg}$ (II) form. This unique observation was made in the 1970s in marlin captured off Hawaii. ${ }^{8}$ Total $\mathrm{Hg}$ 
concentration $\left([\mathrm{Hg}]_{\text {tot }}\right)$ was $4.3 \pm 3.9 \mathrm{mg} / \mathrm{kg}$ fish ww $(n=35)$, only $15.3 \pm 10.2 \%$ of which was organic $(\mathrm{MeHg})$. The average PTWI is $1.3 \times 15.3 \%+4.0 \times 84.7 \%=3.6 \mu \mathrm{g} \mathrm{Hg} / \mathrm{kg}$ bw. The PTWI of a human of $75 \mathrm{~kg}$ body weight is reached for a consumption of $\left(3.610^{-3} \times 75\right) / 4.3=63 \mathrm{~g} \mathrm{ww}$ blue marlin. High predatory fish consumers may have a considerably higher intake of $\mathrm{Hg}$ and largely exceed the PTWI. However, this estimate does not consider the large variability in $\mathrm{Hg}$ bioavailability, which diminishes upon cooking, ${ }^{23,24}$ among other factors.

To be bioavailable during digestion process, $\mathrm{Hg}$ needs first to be released in a bioaccessible form from the food matrix and to cross afterward the intestinal epithelium to reach the bloodstream. In a comprehensive review of 20 studies on human dietary exposure to seafood, Bradley and coworkers ${ }^{24}$ estimated a bioaccessibility range of $\sim 2 \%$ to $100 \%$ for $\mathrm{MeHg}$ and from $0.2 \%$ to $94 \%$ for $\mathrm{Hg}(\mathrm{II})$. The large variability in effective $\mathrm{Hg}$ bioavailability can be explained in the first instance by the diversity of the complexation forms of $\mathrm{Hg}$. Mercury has a high chemical affinity for (1) reduced sulfur (S(-II)) present as thiol groups in organic matter), and (2) cysteine (Cys) residues in peptides (e.g., glutathione, GSH) and proteins, with formation of MeHgCys and $\mathrm{Hg}(\mathrm{Cys})_{2}$ complexes. $^{20,25}$ Nutrients rich in either sulfur functionality modify the bioaccessibility of $\mathrm{Hg}$. In experimental conditions, MeHgCys proved to be less toxic to zebrafish than methylmercury chloride $(\mathrm{MeHgCl}),{ }^{20}$ and complexation of $\mathrm{Hg}(\mathrm{II})$ to thiol groups reduced its absorption across model intestinal epithelium compared to $\mathrm{HgCl}_{2} \cdot{ }^{26}$ Furthermore, $\mathrm{Hg}$ has a higher affinity for reduced $\mathrm{Se}(\mathrm{Se}(-\mathrm{II}))$ than for $\mathrm{S}(-\mathrm{II}),{ }^{27,28}$ and $\mathrm{Hg}$ bonded to $\mathrm{Se}$ has a negligible in vivo absorption rate. ${ }^{29}$ Thus, the degree of exposure to $\mathrm{Hg}$ depends not only on $[\mathrm{Hg}]_{\text {tot }}$ and the $\mathrm{MeHg} / \mathrm{Hg}(\mathrm{II})$ ratio, but also on the molecular identity of $\mathrm{Hg}$ in the gut, which in turn depends on its form in raw and cooked fish meat.

Here, the main study goal was to assess the toxicological risk involved in intake of $\mathrm{Hg}$ from consumption of blue marlin by determining the identity and quantity of the different $\mathrm{Hg}$ species in raw muscle using high energy-resolution X-ray absorption near-edge structure (HR-XANES) spectroscopy. ${ }^{25,}{ }^{30}$ XANES spectra measured at high energy-resolution (HR) provide increased 
chemical and structural sensitivity on $\mathrm{Hg}$ speciation in biomolecules at natural concentration (Figure S1). ${ }^{31-35}$

\section{MATERIALS AND METHODS}

Samples. Eleven fresh fish muscles, otherwise intended for human consumption, were obtained in 2016-2017 from a fishmonger on the island of Moorea (French Polynesia). Each fillet was rapidly freeze-dried, ground to a fine powder, and stored in polyethylene vials for further analyses. The average moisture content of the powder was $72.53 \pm 1.72 \%$.

\section{Molecular analyses for identification of fish fillets to the species level through DNA} barcoding. Genomic DNA was extracted from the eleven fillet powders using the DNeasy Blood and Tissue kit (Qiagen, Valencia CA) The gene of the 5'-end fragment for the mitochondrial cytochrome c oxidase subunit I (COI) was amplified using primers FishF1 and FishR $1^{36}$. PCRs were performed using Type-It Microsatellite (Qiagen) in a $10 \mu \mathrm{l}$ final volume containing $1 \mathrm{X}$ Master Mix, 0.1X of Q-solution, $0.25 \mu \mathrm{M}$ of each primer and 50 to $150 \mathrm{ng}$ of DNA template. PCRs were achieved in Eppendorf with $3 \mathrm{~min}$ at $94{ }^{\circ} \mathrm{C}, 37$ cycles at $94^{\circ} \mathrm{C}$ for $1 \mathrm{~min}, 48^{\circ} \mathrm{C}$ for 1 min and $72^{\circ} \mathrm{C}$ for $90 \mathrm{~s}$, followed by a final step at $72{ }^{\circ} \mathrm{C}$ for $10 \mathrm{~min}$. Polymerase-chain reaction products were sent to Genoscreen (Lille, France) for sequencing on an ABI 3730XL genetic analyzer (Applied Biosystems, Carlsbad, CA, USA) using the forward primer. Sequences of 638 base pair (bp) of a portion of the mtDNA COI gene were retrieved from sequence chromatograms using BioEDIT ${ }^{37}$. The eleven samples shared the exact same COI sequence, which was submitted to the Barcode of Life Data System (BOLD) ${ }^{38}$ for genus and species identification. The COI sequence has $>99 \%$ sequence identity with all Makaira nigricans sequences deposited in public databases and we therefore confirmed that the 11 marlin samples are all Makaira mazara (Jordan \& Snyder, 1901), the Indo-Pacific blue marlin, not genetically differentiated from the Atlantic blue marlin Makaira nigricans at the COI gene. ${ }^{39}$ The nucleotide sequence was deposited in GenBank (http://www.ncbi.nlm.nih.gov) under accession number MW323444. 
$\mathrm{Hg}$ and MeHg analyses. Total $\mathrm{Hg}$ concentrations were determined on 5-15 $\mathrm{mg}$ of homogenized freeze-dried muscle using an Advanced Mercury Analyser (AMA-254, Altec, Czech Republic) calibrated using gravimetric dilution of a Certified Reference Material (CRM) standard solution (1000 $\mu \mathrm{g} / \mathrm{g}$, Trace Select, Merck). Accuracy was assessed on the certified reference material IAEA-436A (Tuna fish flesh, IAEA). The absolute mass detection limit was $0.1 \mathrm{ng} \mathrm{Hg}$, which corresponds to $10 \mathrm{ng} / \mathrm{g}$ of total $\mathrm{Hg}$ for a $10 \mathrm{mg}$ sample. Muscle tissues were analyzed in triplicate with a recovery of $102 \pm 2 \%(n=9)$. The standard uncertainty (RSD) was 4-6\% and the expanded uncertainty $(k=2)$ was $12 \%$.

MeHg was analyzed on $~ 300 \mathrm{mg}$ muscle digested in alkaline solution using an automated methylmercury analyzer (MERX Brooks Rand, Seattle, USA) following established procedure. ${ }^{40}$ The instrument was calibrated by external calibration using volumetric dilution of CRM standard solution $(1000 \mu \mathrm{g} / \mathrm{g}$, Alfa Aesar). Accuracy was assessed with the IAEA-436A reference. The detection limit was $0.5 \mathrm{pg} \mathrm{Hg}$, which corresponds to $3 \mathrm{ng} / \mathrm{g}$ for a $300 \mathrm{mg}$ sample. Muscle tissues were analyzed in triplicate with a recovery of $104 \pm 8 \%(n=8)$. The standard uncertainty (RSD) was $5-10 \%$ and the expanded uncertainty $(k=2)$ was $15 \%$.

Se analysis. Selenium concentrations were determined using Inductively Coupled Plasma Quadrupole Mass Spectrometry (Q-ICP-MS, XSERIES, Thermo Fisher Scientific). 200 mg of freeze-dried tissues were digested with a microwave system (Mars X-press, CEM) in PTFE reactors containing $5 \mathrm{~mL} \mathrm{HNO}_{3}$ (Ultrex, T. T. Baker, Phillipsburg, NJ, USA) and $2 \mathrm{~mL} \mathrm{H}_{2} \mathrm{O}_{2}$ (p.a., Merck). Internal standards (rhenium and rhodium) were added to calibration standards and to sample solutions to correct for matrix interferences and for potential instrument drifts as a result of temperature variations during ICP-MS measurement. Quality assurance and quality control were assessed by procedural test blanks $(n=6)$ and analysis of RM IAEA-407 (fish tissue, IAEA) prepared the same way as the samples. Se recovery for the RM averaged $95 \pm 6 \%$ $(n=3)$. Procedural blanks were always below the detection limit $(0.013 \mu \mathrm{g} / \mathrm{g})$ and the precision of triplicate measurements was 3-6\%. 
HR-XANES spectroscopy. Freeze-dried powder of the marlin skeletal muscles were pressed into pellets and the $\mathrm{Hg} \mathrm{L}_{3}$-edge XANES spectra measured at high energy-resolution (HRXANES) with high-luminosity analyzer crystals ${ }^{41}$ on beamline ID26 at the European Synchrotron Radiation Facility (ESRF). Spectra were collected at a temperature of 10-15 K and a scan time of $15 \mathrm{~s}$ to reduce exposure and repeated at new positions on the sample to increase the signal-tonoise ratio. Scans were monitored carefully for any evidence of radiation damage. The incident energy was scanned from 12260 to $12360 \mathrm{eV}$ in $0.2 \mathrm{eV}$ steps and the spectra were normalized to unity at $\mathrm{E}=12360 \mathrm{eV}$. The identities and relative proportions of the mercury species were determined using a spectral database..$^{25,32-35}$ All reference spectra were considered as a basis for identification, but only diagnostic spectra are discussed herein. The precision of the fit components was estimated to be equal to the variation of their best-fit values when the fit residual (NSS) was increased by $20 \%$. NSS is the normalized sum-squared difference between the data and fit expressed as $\Sigma\left[\left(\mathrm{y}_{\text {data }}-\mathrm{y}_{\mathrm{fit}}\right)^{2}\right] / \Sigma\left(\mathrm{y}_{\text {data }}{ }^{2}\right)$. Further details on data acquisition and analysis can be found elsewhere. ${ }^{25,32,33}$

\section{RESULTS AND DISCUSSION}

Mercury concentration. The eleven fish contained $[\mathrm{Hg}]_{\mathrm{tot}}=1.12 \pm 1.03 \mathrm{mg} / \mathrm{kg} \mathrm{ww}$ and $[\mathrm{MeHg}] /[\mathrm{Hg}]_{\mathrm{tot}}=19.2 \pm 21.6 \%$ (Table S1). Although the French Polynesia fish have less $[\mathrm{Hg}]_{\mathrm{tot}}$ on average than the Hawaiian fish, the two sample lots have similar \% MeHg $(15.3 \pm 10.2 \%$ vs. $19.2 \pm 21.6 \%$ ), and they both exhibit a negative power-law variation of $\% \mathrm{MeHg}$ with $[\mathrm{Hg}]_{\text {tot }}$

(Figure 1a,b). Older (i.e., higher weight) fish specimens contain more $[\mathrm{Hg}]_{\text {tot }}$ and $[\mathrm{MeHg}]_{\text {tot }}^{8}$ (Figure 1c), as a result of their lifespan bioaccumulation of $\mathrm{Hg}$, but much less $\% \mathrm{MeHg}$. The power-law relationship of $\% \mathrm{MeHg}$ against $[\mathrm{Hg}]_{\text {tot }}$ has been observed previously in the brain of southern giant petrel seabirds. ${ }^{33}$ Using HR-XANES, the decrease of $\% \mathrm{MeHg}$ with $[\mathrm{Hg}]_{\text {tot }}$ increase in petrel brains was shown to result from the detoxification of $\mathrm{MeHgCys}$ as tiemannite $(\mathrm{HgSe}),{ }^{33}$ which is an insoluble form of $\mathrm{Hg}\left(K_{\mathrm{sp}}=10^{-56.6 \pm 0.2}\right){ }^{42}$ 
Mercury speciation. The chemical forms of $\mathrm{Hg}$ were determined in the two fish (specimens 1 and 3) having the lowest proportion of $\mathrm{MeHg}$ (3.6\% and 3.8\%, respectively, Table S1). Fish specimen 1 has $[\mathrm{Hg}]_{\text {tot }}=2.60 \mathrm{mg} / \mathrm{kg} \mathrm{ww}$ and specimen 3 has $[\mathrm{Hg}]_{\mathrm{tot}}=2.30 \mathrm{mg} / \mathrm{kg} \mathrm{ww}$. Their HRXANES spectra are indistinguishable, indicating similar or identical $\mathrm{Hg}$ speciation (Figure 2a). They closely resemble the spectrum of a petrel muscle containing $26.6 \mathrm{mg} \mathrm{Hg} / \mathrm{kg}$ dry weight (dw) speciated as $67 \pm 8 \% \mathrm{Hg}(\mathrm{Sec})_{4}+33 \pm 8 \% \mathrm{HgSe}$ (Figure $2 \mathrm{~b}$ ). $\mathrm{Hg}(\mathrm{Sec})_{4}$ is a four-coordinate selenocysteinate $\left(\mathrm{Hg}(\mathrm{Sec})_{4}\right)$ complex, and an intermediate species in the detoxification of MeHgCys into $\mathrm{HgSe}$ according to the chain reaction MeHgCys $\rightarrow \mathrm{Hg}(\mathrm{Sec})_{4} \rightarrow \mathrm{Hg}_{x}(\mathrm{Se}, \mathrm{Sec})_{y} \rightarrow$ $\mathrm{HgSe}^{33}$ Note that $\mathrm{Hg}$ is tetrahedrally coordinated to four $\mathrm{Se}$ atoms in the three selenious compounds. The two marlin spectra were fit with $57 \pm 10 \% \mathrm{Hg}(\mathrm{Sec})_{4}+43 \pm 10 \% \mathrm{HgSe}$, with a detection limit of $6 \%$ for MeHgCys and $12 \%$ for $\mathrm{Hg}(\mathrm{Cys})_{2}$ (Figure 2c). The frequency of the top edge of metacinnabar $(\beta-\mathrm{HgS})$ is shifted relative to that of $\mathrm{HgSe}$ (Fig. S1d), which excludes the existence of a $\mathrm{HgS}_{\mathrm{x}} \mathrm{Se}_{1-\mathrm{y}}$ solid-solution. Adding the $\beta$-HgS reference to the $\mathrm{Hg}(\mathrm{Sec})_{4}+\mathrm{HgSe}$ two-component fit yielded a negative fraction for $\beta$-HgS. The MeHgCys spectrum has a sharp absorption line at $12279.8 \mathrm{eV}$ in the rising part of the absorption edge, well observed in albacore tuna (Thunnus alalunga) containing $>95 \% \mathrm{MeHg}$ (Figures 2c and S2). The fit residual of the marlin spectra has a small amplitude at this position, which confirms that a small proportion of $\mathrm{Hg}$ is methylated in the two fish specimens (arrow in Figure 2c). The higher proportion of $\mathrm{HgSe}$ in marlin $(43 \pm 10 \%)$ relative to petrel $(33 \pm 8 \%)$ is seen on the marlin spectra as significant absorption dips at three energies pointed out with arrows in Figure $2 b$. These positions correspond to minima in the HR-XANES of $\mathrm{HgSe}$ that are not observed in $\mathrm{Hg}(\mathrm{Sec})_{4}$ (Figure 2d). Although the marlin spectra are well reconstructed with the $\mathrm{Hg}(\mathrm{Sec})_{4}$ and $\mathrm{HgSe}$ references, the fit results are compatible with the occurrence of multinuclear $\mathrm{Hg}_{x}(\mathrm{Se}, \mathrm{Sec})_{y}$ clusters $(y<4 x)$, as HRXANES cannot differentiate $\mathrm{Hg}_{x}(\mathrm{Se}, \mathrm{Sec})_{y}$ from a mixture of $\mathrm{Hg}(\mathrm{Sec})_{4}$ and $\mathrm{HgSe}$, and even $\mathrm{Hg}_{x}(\mathrm{Se}, \mathrm{Sec})_{y}$ from $\mathrm{Hg}(\mathrm{Sec})_{4}$ if the structure of the nanoclusters is highly disordered (Figure $\left.2 \mathrm{e}\right) .{ }^{33}$ The biomineralization of MeHgCys as $\mathrm{HgSe}$ implies demethylation capability of the muscle 
tissue of marlin via the formation of $\mathrm{Hg}(\mathrm{Sec})_{4}$ complex that was only known to exist in the liver of freshwater fish, ${ }^{32}$ in liver, kidneys, muscle, and brain of giant petrel seabirds, ${ }^{33}$ and in liver, kidneys, and muscle of the Clark's grebe water bird. ${ }^{32}$

Toxicological risk. The speciation results provide a more precise evaluation of the toxicological risk resulting from the consumption of marlin. Since $\mathrm{Hg}$-Se species are either nonbioavailable, and little or non-toxic if they are bioavailable, ${ }^{28,43-46}$ the amount of toxic $\mathrm{Hg}$ reaching the bloodstream can be estimated from the concentration of MeHg only. The PTWI of a human of $75 \mathrm{~kg}$ is reached for a consumption of $\left(1.310^{-3} \times 75\right) / 0.093=1048 \mathrm{~g}$ ww blue marlin 1 , where 1.3 is the MeHg PTWI per bw and $[\mathrm{MeHg}]_{\text {tot }}=0.093 \mathrm{mg} / \mathrm{kg}$ (Table S1). Alternatively, if the actual form of $\mathrm{Hg}$ is ignored and all inorganic $\mathrm{Hg}$ considered to be speciated as $\mathrm{Hg}(\mathrm{Cys})_{2}$, the average PTWI is $1.3 \times 3.6 \%+4 \times 96.4 \%=3.9 \mu \mathrm{g} \mathrm{Hg} / \mathrm{kg}$ bw, where $\% \mathrm{MeHg}=3.6 \%$ and $\% \mathrm{Hg}(\mathrm{Cys})_{2}=96.4 \%$. The PTWI of a human of $75 \mathrm{~kg}$ is reached for a consumption of $\left(3.910^{-3} \times\right.$ $75) / 2.60=112 \mathrm{~g} \mathrm{ww}$ blue marlin 1 , where $[\mathrm{Hg}]_{\mathrm{tot}}=2.60 \mathrm{mg} / \mathrm{kg}$. Thus, omitting the actual form of $\mathrm{Hg}$ overestimates 10 times the dietary exposure to $\mathrm{Hg}(1.1 / 0.11)$. The tolerable weekly meal weight covaries with $[\mathrm{MeHg}]_{\text {tot. }}$ For the eleven marlins studied here, it ranges between 505 and $3750 \mathrm{~g}$ for a human of $75 \mathrm{~kg}$ (Table S1). For the Hawaiian fish, the range is 103-1625 $\mathrm{g}$. The heavier the fish, the lower is the tolerable weekly meal, as $[\mathrm{MeHg}]_{\text {tot }}$ increases with the body weight (Figure 1d).

Mercury-selenium antagonism. Mercury exerts its toxicity via complexation to cysteinyl (Cys) and selenocysteinyl (Sec) metal-binding sites in proteins. ${ }^{32,47}$ The binding of $\mathrm{Hg}$ to $\mathrm{Sec}$ residues reduces Se supply for the biosynthesis of vital selenoproteins. It is usually considered that $\mathrm{Hg}$ is detoxified as $\mathrm{HgSe}$, and therefore is without toxicological consequences when the molar difference $[\mathrm{Se}]-[\mathrm{Hg}]$ is $>0$, or the molar ratio $[\mathrm{Hg}]_{\mathrm{mol}} /[\mathrm{Se}]_{\mathrm{mol}}<1$, leaving sufficient bioavailable Se for seleoprotein synthesis and activity. ${ }^{28,48} \mathrm{The}[\mathrm{Hg}]_{\mathrm{mol}} /[\mathrm{Se}]_{\mathrm{mol}}$ ratio represents the fraction of Se, to total Se, bound to $\mathrm{Hg}$. This criterion breaks down when $\mathrm{Hg}$ is also bonded to four Sec residues $\left(\mathrm{Hg}(\mathrm{Sec})_{4}\right)$, because $\mathrm{Hg}$ is no longer in equimolar stoichiometry with $\mathrm{Se}$ in the 
$\mathrm{Hg}(\mathrm{Sec})_{4}$ complex $(\mathrm{Se} / \mathrm{Hg}=4)$, in contrast to $\mathrm{HgSe}$. There is less bioavailable Se than what chemical analysis estimates. The chemical ratios of specimens 1 and 3 are $[\mathrm{Hg}]_{\mathrm{mol}}^{\text {chem }} /[\mathrm{Se}]_{\mathrm{mol}}^{\text {chem }}=$ 0.72 and 0.56 , respectively, and the ratios of the other marlins are $0.05 \leq[\mathrm{Se}]_{\mathrm{mol}}^{\text {chem }} /[\mathrm{Hg}]_{\mathrm{mol}}^{\text {chem }} \leq$ 0.65 , suggesting that the amount of Se is high enough to counteract some of the health hazards of $\mathrm{Hg}$ upon selenoenzymes (Table S1). However, since $57 \%$ of the Se-bound $\mathrm{Hg}$ is speciated as $\mathrm{Hg}(\mathrm{Sec})_{4}$ (and/or $\left.\mathrm{Hg}_{x}(\mathrm{Se}, \mathrm{Sec})_{y}\right)$, there is less bioavailable Se than what chemical analysis estimates. The biological $[\mathrm{Hg}]_{\text {mol }}^{\text {biol }} /[\mathrm{Se}]_{\text {mol }}^{\text {biol }}$ ratio derived from HR-XANES is higher than $[\mathrm{Hg}]_{\mathrm{mol}}^{\text {chem }} /[\mathrm{Se}]_{\mathrm{mol}}^{\text {chem }}$. If all inorganic $\mathrm{Hg}$ is speciated as $\mathrm{Hg}(\mathrm{Sec})_{4}$ and $\mathrm{HgSe}$, the biological ratio is ${ }^{33}$

$$
[\mathrm{Hg}]_{\mathrm{mol}}^{\text {biol }} /[\mathrm{Se}]_{\mathrm{mol}}^{\text {biol }}=[\mathrm{Hg}]_{\mathrm{mol}}^{\text {chem }} /[\mathrm{Se}]_{\mathrm{mol}}^{\text {chem }} \times\left(\% \mathrm{HgSe}+4 \times \% \mathrm{Hg}(\mathrm{Sec})_{4}\right) / 100
$$

Specimen 1 has $[\mathrm{Hg}]_{\mathrm{mol}}^{\mathrm{biol}} /[\mathrm{Se}]_{\mathrm{mol}}^{\mathrm{biol}}=0.72 \times(0.43+4 \times 0.57)=1.9$, and specimen 2 has $[\mathrm{Hg}]_{\mathrm{mol}}^{\text {biol }} /[\mathrm{Se}]_{\mathrm{mol}}^{\text {biol }}=0.56 \times(0.43+4 \times 0.57)=1.5$. The two biological ratios exceed the threshold value of 1 , suggesting that all $\mathrm{Se}$ is bonded to $\mathrm{Hg}$. Another way to look at it is to calculate the concentration of bioavailable Se: $[\mathrm{Se}]_{\text {bio }}=\left(1-[\mathrm{Hg}]_{\mathrm{mol}}^{\text {biol }} /[\mathrm{Se}]_{\mathrm{mol}}^{\text {biol }}\right) \times[\mathrm{Se}]_{\mathrm{tot} \cdot}{ }^{33}[\mathrm{Se}]_{\text {bio }}$ is negative for the two fish specimens, meaning that the muscle tissues are depleted in bioavailable Se. Since $[\mathrm{Se}]_{\text {bio }}$ obviously cannot be negative, the calculation supports the occurrence of $\operatorname{Hg}_{x}(\operatorname{Se}, \operatorname{Sec})_{y}$ because $y<4 x$. Thus, Se-deficiency disorders may appear as little to no Hg-unbound Se appears to remain for biological processes. ${ }^{3,28} \mathrm{We}$ conclude that consumption of specimens 1 and 3 is not a chief source of dietary Se essential to selenoenzyme metabolism and detoxification of MeHgCys.

Fish consumption advisory. This study highlights the importance of considering more systematically the amount and chemical forms of inorganic $\mathrm{Hg}$ to evaluate human exposure and risk, as Se- and S-bound $\mathrm{Hg}(\mathrm{II})$ have quite different toxicological implications. Marlins fished in Hawaïan and French Polynesian waters contain $\mathrm{Hg}(\mathrm{Sec})_{4}$ and $\mathrm{HgSe}$ species, which are not thought to be very hazardous, and various amounts of MeHgCys, which is highly hazardous. 
Thus, monitoring the concentration of $\mathrm{MeHg}$ in commercial blue marlin appears sufficient for food safety control. To date, cheap methodology exists to measure $\mathrm{MeHg}$ routinely. ${ }^{49} \mathrm{As}$ a general recommendation, one should avoid regularly consuming the heaviest blue marlins (> $\sim 100 \mathrm{~kg}$ ), as body weight (or length) is a good predicator of tissue $\mathrm{MeHg}$ with larger fish specimens having higher levels of $\mathrm{MeHg}$ than smaller specimens (Figure 1c), and should cook the food, as boiling and grilling diminish the bioaccessibility of $\mathrm{Hg}$ in fish meat. ${ }^{23,24}$

\section{ASSOCIATED CONTENT}

\section{Supporting Information}

The Supporting Information is available free of charge on the ACS Publications website at DOI: Supplementary table S1 and figures S1 and S2 (PDF).

\section{ACKNOWLEDGEMENTS}

Support was provided to A.M. and P.G. by the ANR under grant ANR-10-EQPX-27-01 (EcoX Equipex), and to P.B. by the Institut Universitaire de France. On behalf of S.A., M.M. E.V. and P.W.S., the IAEA is grateful to the Government of the Principality of Monaco for its support to Environment Laboratories.

\section{AUTHOR INFORMATION}

Alain Manceau: 0000-0003-0845-611X

Marc Metian: 0000-0003-1485-5029

Paco Bustamante : 0000-0003-3877-9390

\section{Note}

The authors declare no competing interests. 


\section{REFERENCES}

(1) Ha, E.; Basu, N.; Bose-O'Reilly, S.; Dorea, J. G.; McSorley, E.; Sakamoto, M.; Chan, H. M. Current progress on understanding the impact of mercury on human health. Environ. Res. 2017, $152,419-433$.

(2) Roman, M.; Jitaru, P.; Barbante, C. Selenium biochemistry and its role for human health. Metallomics 2014, 6, 25-54.

(3) Burk, R. F.; Hill, K. E. Regulation of selenium metabolism and transport. In Annu. Rev. Nutr., Bowman, B. A.; Stover, P. J., Eds. 2015; Vol. 35, pp 109-134.

(4) Hill, K. E.; Zhou, J. D.; McMahan, W. J.; Motley, A. K.; Atkins, J. F.; Gesteland, R. F.;

Burk, R. F. Deletion of selenoprotein $\mathrm{P}$ alters distribution of selenium in the mouse. J. Biol. Chem. 2003, 278, 13640-13646.

(5) Renzoni, A.; Zino, F.; Franchi, E. Mercury levels along the food chain and risk for exposed populations. Environ. Res. 1998, 77, 68-72.

(6) Mason, R. P.; Choi, A. L.; Fitzgerald, W. F.; Hammerschmidt, C. R.; Lamborg, C. H.; Soerensen, A. L.; Sunderland, E. M. Mercury biogeochemical cycling in the ocean and policy implications. Environ. Res. 2012, 119, 101-117.

(7) Ahmad, N. I.; Noh, M. F. M.; Mahiyuddin, W. R. W.; Jaafar, H.; Ishak, I.; Azmi, W.; Veloo, Y.; Hairi, M. H. Mercury levels of marine fish commonly consumed in Peninsular Malaysia. Environ. Sci. Pollut. Res. 2015, 22, 3672-3686.

(8) Schultz, C. D.; Crear, D. The distribution of total and organic mercury in seven tissues of the Pacific blue marlin, Makaira nigricans. Pac. Sci. 1976, 30, 101-107.

(9) Forsyth, D. S.; Casey, V.; Dabeka, R. W.; McKenzie, A. Methylmercury levels in predatory fish species marketed in Canada. Food Add. Contam. A 2004, 21, 849-856.

(10) Kojadinovic, J.; Potier, M.; Le Corre, M.; Cosson, R. P.; Bustamante, P. Mercury content in commercial pelagic fish and its risk assessment in the Western Indian Ocean. Sci. Tot. Environ. 2006, 366, 688-700. 
(11) Cai, Y.; Rooker, J. R.; Gill, G. A.; Turner, J. P. Bioaccumulation of mercury in pelagic fishes from the northern Gulf of Mexico. Can. J. Fish Aquat. Sci. 2007, 64, 458-469.

(12) Kaneko, J. J.; Ralston, N. V. C. Selenium and mercury in pelagic fish in the Central North Pacific near Hawaii. Biol. Trace Elem. Res. 2007, 119, 242-254.

(13) Glover, J. B.; Domino, M. E.; Altman, K. C.; Dillman, J. W.; Castleberry, W. S.; Eidson, J. P.; Mattocks, M. Mercury in South Carolina fishes, USA. Ecotoxicology 2010, 19, 781-795.

(14) Vega-Sanchez, B.; Ortega-Garcia, S.; Ruelas-Inzunza, J.; Frias-Espericueta, M.; EscobarSanchez, O.; Guzman-Rendon, J. Mercury in the blue marlin (Makaira nigricans) from the southern Gulf of California: Tissue distribution and inter-annual variation (2005-2012). B. Environ. Contam. Tox. 2017, 98, 156-161.

(15) FAO/WHO (Food and Agriculture Organization of the United Nations/World Health Organization) Safety evaluation of certain food additives and contaminants. WHO Food Additives Series 2004, 52, 565-623.

(16) FAO/WHO (Food and Agriculture Organization of the United Nations/World Health Organization) Safety evaluation of certain food additives and contaminants. Methylmercury. WHO Food Additives Series 2011, 63, 605-684.

(17) Authority), E. E. F. S. Scientific opinion on the risk for public health related to the presence of mercury and methylmercury in food. EFSA J. 2012, 10, n 2985.

(18) Clarkson, T. W.; Magos, L. The toxicology of mercury and its chemical compounds. Crit. Rev. Toxicol. 2006, 36, 609-662.

(19) Wagemann, R.; Trebacz, E.; Hunt, R.; Boila, G. Percent methylmercury and organic mercury in tissues of marine mammals and fish using different experimental and calculation methods. Environ. Toxicol. Chem. 1997, 16, 1859-1866.

(20) Harris, H. H.; Pickering, I. J.; George, G. N. The chemical form of mercury in fish. Science 2003, 301, 1203. 
(21) Krystek, P.; Ritsema, R. Mercury speciation in thawed out and refrozen fish samples by gas chromatography coupled to inductively coupled plasma mass spectrometry and atomic fluorescence spectroscopy. Anal. Bioanal. Chem. 2005, 381, 354-359.

(22) Hight, S. C.; Cheng, J. Determination of methylmercury and estimation of total mercury in seafood using high performance liquid chromatography (HPLC) and inductively coupled plasmamass spectrometry (ICP-MS): Method development and validation. Anal. Chim. Acta, 2006, 567, 160-172.

(23) Afonso, C.; Costa, S.; Cardoso, C.; Oliveira, R.; Lourenco, H. M.; Viula, A.; Batista, I.; Coelho, I.; Nunes, M. L. Benefits and risks associated with consumption of raw, cooked, and canned tuna (Thunnus spp.) based on the bioaccessibility of selenium and methylmercury. Environ. Res. 2015, 143, 130-137.

(24) Bradley, M. A.; Barst, B. D.; Basu, N. A review of mercury bioavailability in humans and fish. Int. J. Environ. Res. Public Health 2017, 14.

(25) Bourdineaud, J. P.; Gonzalez-Rey, M.; Rovezzi, M.; Gatzel, P.; Nagy, K. L.; Manceau, A. Divalent mercury from dissolved organic matter is bioavailable to fish and accumulates as dithiolate and tetrathiolate complexes. Environ. Sci. Technol. 2019, 53, 4880-4891.

(26) Jadan-Piedra, C.; Velez, D.; Devesa, V. In vitro evaluation of dietary compounds to reduce mercury bioavailability. Food Chem. 2018, 248, 353-359.

(27) Dyrssen, D.; Wedborg, M. The sulfur-mercury(II) system in natural waters. Water Air Soil Pollut. 1991, 56, 507-519.

(28) Ralston, N. V. C.; Raymond, L. J. Mercury's neurotoxicity is characterized by its disruption of selenium biochemistry. BBA-Gen. Sub. 2018, 1862, 2405-2416.

(29) Endo, T.; Haraguchi, K.; Sakata, M. Renal toxicity in rats after oral administration of mercury-contaminated boiled whale livers marketed for human consumption. Arch. Environ. Contam. Toxicol. 2003, 44, 412-416. 
(30) Thomas, S. A.; Mishra, B.; Myneni, S. C. B. Cellular mercury coordination environment, and not cell surface ligands, influence bacterial methylmercury production. Environ. Sci. Technol. 2020, 54, 3960-3968.

(31) Manceau, A.; Enescu, M.; Simionovici, A.; Lanson, M.; Gonzalez-Rey, M.; Rovezzi, M.; Tucoulou, R.; Glatzel, P.; Nagy, K. L.; Bourdineaud, J.-P. Chemical forms of mercury in human hair reveal sources of exposure. Environ. Sci. Technol. 2016, 50, 10721-10729.

(32) Manceau, A.; Bourdineaud, J. P.; Oliveira, R. B.; Sarrazin, S. L. F.; Krabbenhoft, D. P.; Eagles-Smith, C. A.; Ackerman, J. T.; Stewart, A. R.; Ward-Deitrich, C.; Busto, M. E. D.; Goenaga-Infante, H.; Wack, A.; Retegan, M.; Detlefs, B.; Glatzel, P.; Bustamante, P.; Nagy, K. L.; Poulin, B. A. Demethylation of methylmercury in bird, fish, and earthworm. Environ. Sci. Technol. 2021, 55, 1527-1534.

(33) Manceau, A.; Gaillot, A. C.; Glatzel, P.; Cherel, Y.; Bustamante, P. In vivo formation of HgSe nanoparticles and Hg-tetraselenolate complex from methylmercury in seabird Implications for the Hg-Se antagonism. Environ. Sci. Technol. 2021, 55, 1515-1526.

(34) Manceau, A.; Bustamante, P.; Haouz, A.; Bourdineaud, J. P.; Gonzalez-Rey, M.; Geertsen, V.; Barruet, E.; Rovezzi, M.; Glatzel, P.; Pin, S. Mercury(II) binding to metallothionein in Mytilus edulis revealed by high energy-resolution XANES spectroscopy. Chem-Eur J. 2019, 25, 997-1009.

(35) Manceau, A.; Wang, J.; Rovezzi, M.; Glatzel, P.; Feng, X. Biogenesis of mercury-sulfur nanoparticles in plant leaves from atmospheric gaseous mercury. Environ. Sci. Technol. 2018, 52, $3935-3948$.

(36) Ward, R. D.; Zemlak, T. S.; Innes, B. H.; Last, P. R.; JHebert, P. D. N. DNA barcoding Australia's fish species. Philos. T. R. Soc. B 2005, 360, 1847-1857.

(37) Hall, T. A. BioEdit: A user-friendly biological sequence alignment editor and analysis program for Windows 95/98/NT. Nucleic Acids Symposium Series 1999, 41, 95-98. 
(38) Ratnasingham, S.; Hebert, P. D. N. BOLD: the Barcode of Life Data System (www.barcodinglife.org). Mol. Ecol. Notes 2007, 7, 355-364.

(39) Williams, S. M.; McDowell, J. R.; Bennett, M.; Graves, J. E.; Ovenden, J. R. Analysis of whole mitochondrial genome sequences increases phylogenetic resolution of istiophorid billfishes. Bull. Mar. Sci. 2018, 94, 73-84.

(40) Taylor, V. F.; Carter, A.; Davies, C.; Jackson, B. P. Trace-level automated mercury speciation analysis. Anal. Methods 2011, 3, 1143-1148.

(41) Rovezzi, M.; Lapras, C.; Manceau, A.; Glatzel, P.; Verbeni, R. High energy-resolution xray spectroscopy at ultra-high dilution with spherically bent crystal analyzers of $0.5 \mathrm{~m}$ radius. Rev. Sci. Instr. 2017, 88, 013108.

(42) Mehra, M. C.; Gubeli, A. O. The complexing characteristics of insoluble selenides Pt. 3. Mercuric selenide. J. Less Common Met. 1971, 25, 221-224.

(43) Ohi, G.; Nishigaki, S.; Seki, H.; Tamura, Y.; Maki, T.; Konno, H.; Ochiai, S.; Yamada, H.; Shimamura, Y.; Mizoguchi, I.; Yagyu, H. Efficacy of selenium in tuna and selenite in modufying methylmercury intoxication. Environ. Res. 1976, 12, 49-58.

(44) Cabanero, A. I.; Madrid, Y.; Camara, C. Mercury-selenium species ratio in representative fish samples and their bioaccessibility by an in vitro digestion method. Biol. Trace Elem. Res. 2007, 119, 195-211.

(45) Korbas, M.; O'Donoghue, J. L.; Watson, G. E.; Pickering, I. J.; Singh, S. P.; Myers, G. J.; Clarkson, T. W.; George, G. N. The chemical nature of mercury in human brain following poisoning or environmental exposure. ACS Chem. Neurosci. 2010, 1, 810-818.

(46) Dauplais, M.; Lazard, M.; Blanquet, S.; Plateau, P. Neutralization by metal ions of the toxicity of sodium selenide. Plos One 2013, $8, \mathrm{n}^{\circ}$ e54353.

(47) Manceau, A.; Nagy, K. L.; Glatzel, P.; Bourdineaud, J. P. Acute toxicity of divalent mercury to bacteria explained by the formation of dicysteinate and tetracysteinate complexes 
bound to proteins in Escherichia coli and Bacillus subtilis. Environ. Sci. Technol. 2021, 55, 36123623.

(48) Falnoga, I.; Tusek-Znidaric, M.; Stegnar, P. The influence of long-term mercury exposure on selenium availability in tissues: An evaluation of data. Biometals 2006, 19, 283-294.

(49) Azemard, S.; Vassileva, E. Determination of methylmercury in marine biota samples with advanced mercury analyzer: Method validation. Food Chem. 2015, 176, 367-375.

\section{LEGENDS OF FIGURES}

Figure 1. Chemical analyses. Proportion of methylmercury ( $\mathrm{MeHg}$ ) against total $\mathrm{Hg}$ concentration in blue marlin muscle from Hawaii (a), and from French Polynesia (b). (c) Regression analysis of $\mathrm{MeHg}$ concentration in muscle tissue of Hawaii marlin against the fish weight, showing that the MeHg content builds up over time. One outlier fish specimen weighing $415 \mathrm{~kg}$ has been omitted. (d) Provisional Tolerable Weekly Intake (PTWI) of Hawaii marlin for a human of $75 \mathrm{~kg}$ body weight as a function of the fish weight. Data from the Hawaii fish are from Schultz and Crear. ${ }^{8}$

Figure 2. Chemical forms of $\mathrm{Hg}$ in marlin muscle derived from $\mathrm{Hg} \mathrm{L}_{3}$-edge $\mathrm{HR}$-XANES spectroscopy. (a) Spectra from the two fish specimens having the lowest proportion of $\mathrm{MeHg}$ (Table S1). (b) Spectrum of marlin with muscle spectra from albacore tuna $\left([\mathrm{Hg}]_{\mathrm{tot}}=0.31 \mathrm{mg} / \mathrm{kg}\right.$ $\mathrm{WW}=1.17 \mathrm{mg} / \mathrm{kg} \mathrm{dw})$, and giant southern petrel $\left([\mathrm{Hg}]_{\mathrm{tot}}=42.0 \mathrm{mg} / \mathrm{kg} \mathrm{dw}\right) .{ }^{33}$ (c) Fit of the marlin spectrum with $57 \pm 10 \% \mathrm{Hg}(\mathrm{Sec})_{4}+43 \pm 10 \% \mathrm{HgSe}$. (d) Spectra of the $\mathrm{Hg}(\mathrm{Sec})_{4}$ complex and HgSe. NSS is the normalized sum-squared residual expressed as $\Sigma\left[\left(\mathrm{y}_{2}-\mathrm{y}_{1}\right)^{2}\right] / \Sigma\left(\mathrm{y}_{2}^{2}\right)$. (e) Ball-andstick representations of the linear coordination of $\mathrm{Hg}$ in $\mathrm{MeHgCys}$ and its four-fold coordination to selenocysteine in $\mathrm{Hg}(\mathrm{Sec})_{4}$, polyhedral representation of the $\mathrm{Hg}_{3}(\mathrm{Sec})_{9}$ cluster as an example of 
$\mathrm{Hg}_{x}(\mathrm{Se}, \mathrm{Sec})_{y}$ cluster, and portion of the $\mathrm{HgSe}$ structure. Dark red, purple, yellow, gray, and light gray spheres represent $\mathrm{Hg}, \mathrm{Se}, \mathrm{S}, \mathrm{C}$, and $\mathrm{H}$, respectively.
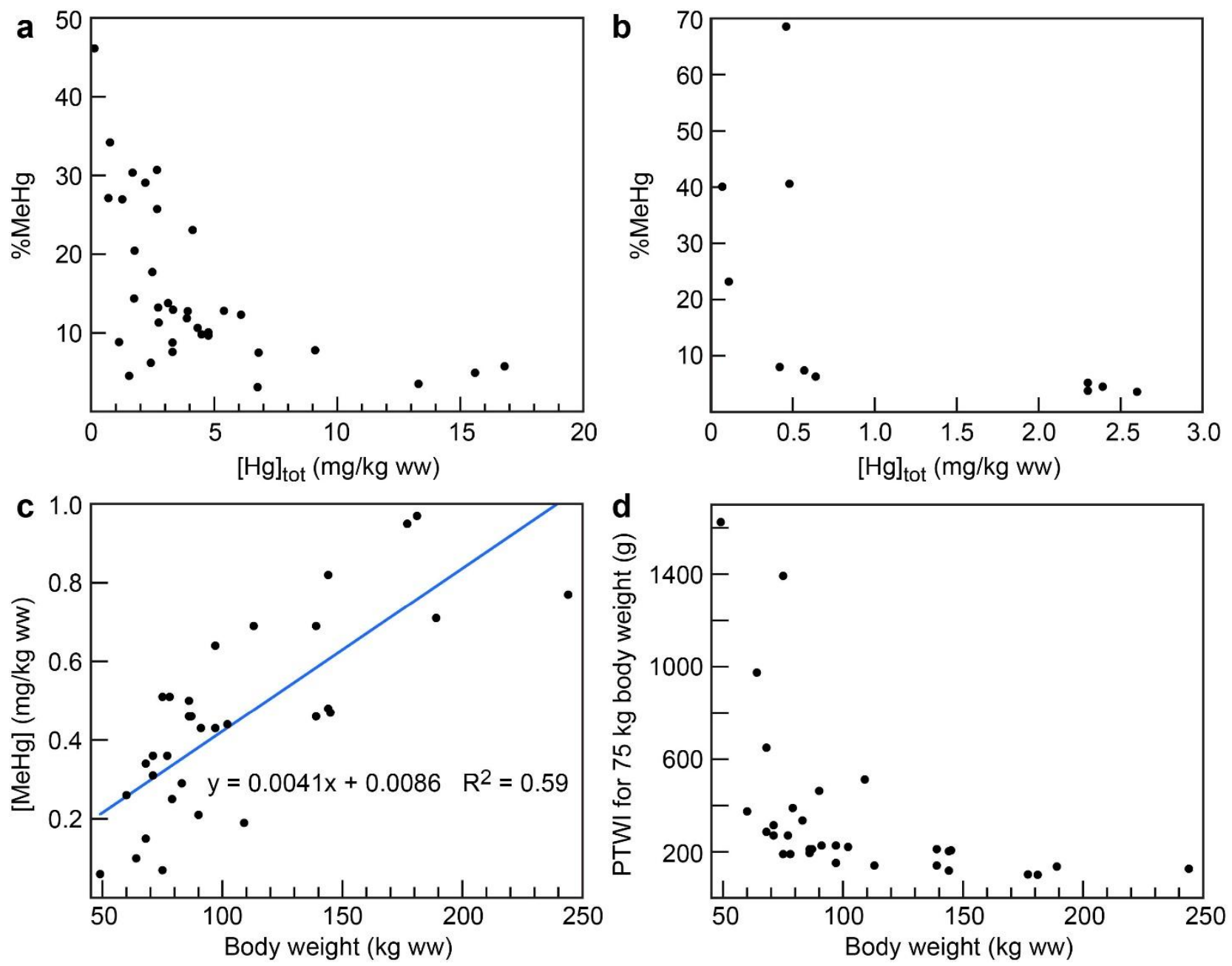

Figure 1 

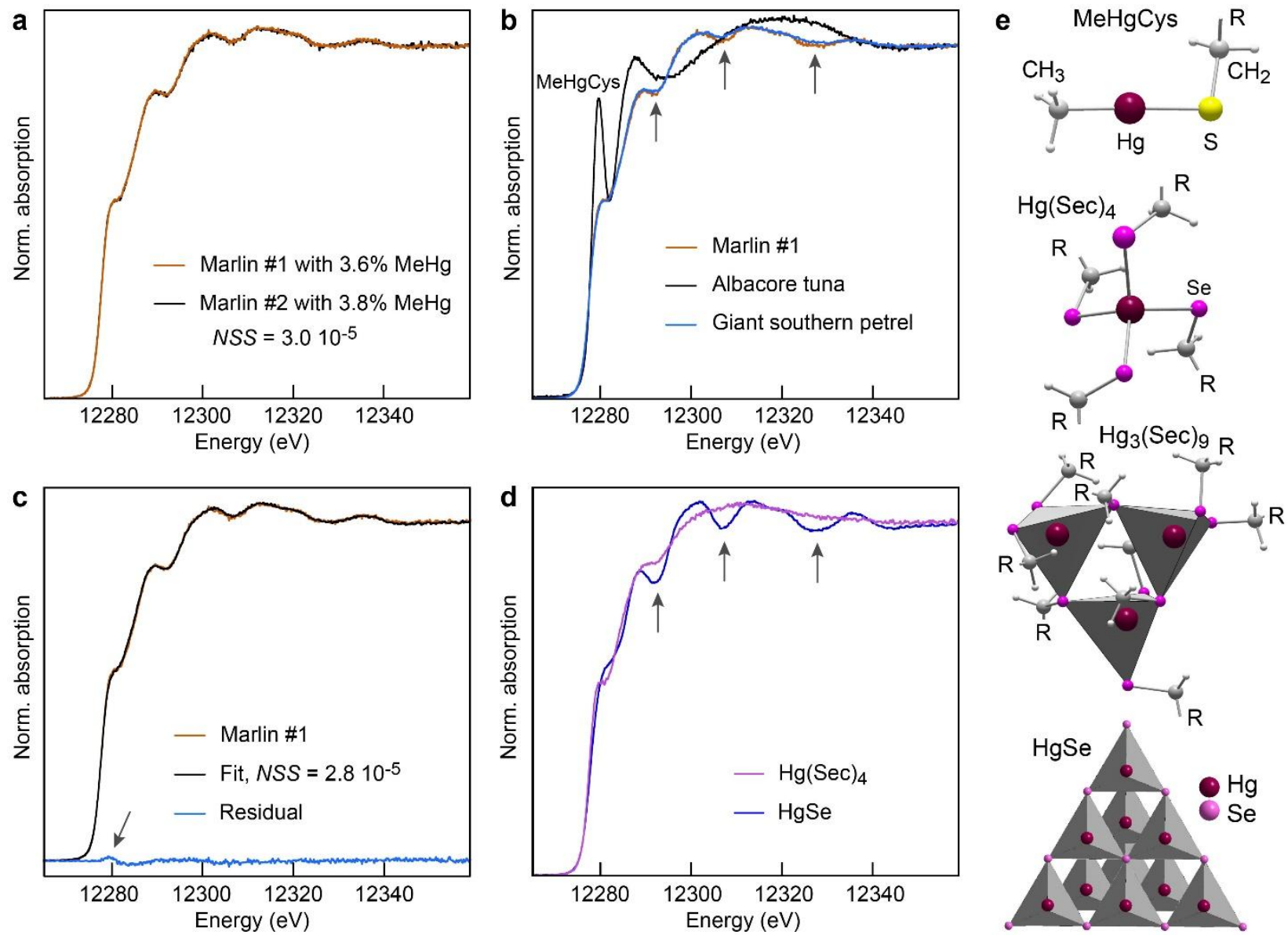

Figure 2 


\section{Supplementary Information}

The chemical forms of mercury in blue marlin billfish: Implications for human exposure

Alain Manceau ${ }^{1, *}$, Sabine Azemard ${ }^{2}$, Laetitia Hédouin ${ }^{3,4}$, Emilya Vassileva ${ }^{2}$, David Lecchini ${ }^{3,4}$,

Cécile Fauvelot ${ }^{3,5,6}$, Peter W. Swarzenski ${ }^{2}$, Pieter Glatzel ${ }^{7}$, Paco Bustamante ${ }^{8}$ and Marc Metian ${ }^{2, *}$

${ }^{1}$ Université Grenoble Alpes, CNRS, ISTerre, F-38000 Grenoble, France

${ }^{2}$ International Atomic Energy Agency (IAEA), Environment Laboratories, MC-98000 Principality of Monaco, Monaco

${ }^{3}$ Université de Perpignan, Laboratoire d'Excellence CORAIL, F-66100 Perpignan, France

${ }^{4}$ PSL Université Paris, EPHE-UPVD-CNRS, CRIOBE, F-98729 Moorea, French Polynesia

${ }^{5}$ IRD, Université de la Réunion, CNRS, IFREMER, Université de la Nouvelle-Calédonie, ENTROPIE, F-06230 Villefranche-sur-Mer, France

${ }^{6}$ Sorbonne Université, CNRS, Laboratoire d'Océanographie de Villefranche, F-06230 Villefranche-sur-Mer, France

${ }^{7}$ European Synchrotron Radiation Facility (ESRF), F-38000, Grenoble, France

${ }^{8}$ La Rochelle Université, CNRS, Littoral Environnement et Sociétés (LIENSs), F-17000 La Rochelle, France 
Table S1. Total concentrations in $\mathrm{mg} / \mathrm{kg}$ of $\mathrm{Hg}$, $\mathrm{MeHg}$, and $\mathrm{Se}$, proportions of $\mathrm{MeHg}$ to total $\mathrm{Hg}$, total $\mathrm{Hg}$ to total Se molar ratios, and provisional tolerable weekly intake for a consumer weighing $75 \mathrm{~kg}$.

\begin{tabular}{lcccccccc} 
Specimen & {$[\mathbf{H g}]_{\text {tot }}(\mathbf{d w})$} & {$[\mathbf{H g}]_{\text {tot }}(\mathbf{w w})$} & {$[\mathbf{M e H g}](\mathbf{d w})$} & {$[\mathbf{M e H g}](\mathbf{w w})$} & $\mathbf{\%} \mathbf{M e H g}$ & {$[\mathbf{S e}]_{\text {tot }}(\mathbf{d w})$} & {$[\mathbf{H g}] /[\mathbf{S e}]$} & PTWI $(\mathbf{g})$ \\
\hline 1 & 9.45 & 2.60 & 0.340 & 0.093 & 3.6 & 5.15 & 0.72 & 1048 \\
2 & 8.68 & 2.39 & 0.391 & 0.107 & 4.5 & 5.26 & 0.65 & 911 \\
3 & 8.38 & 2.30 & 0.319 & 0.088 & 3.8 & 5.88 & 0.56 & 1108 \\
4 & 8.37 & 2.30 & 0.434 & 0.119 & 5.2 & - & - & 819 \\
5 & 2.34 & 0.64 & 0.148 & 0.041 & 6.3 & 3.10 & 0.30 & 2378 \\
6 & 2.07 & 0.57 & 0.153 & 0.042 & 7.4 & 2.86 & 0.29 & 2321 \\
7 & 1.73 & 0.48 & 0.704 & 0.193 & 40.6 & 2.64 & 0.26 & 505 \\
8 & 1.68 & 0.46 & 1.150 & 0.316 & 68.6 & - & - & 309 \\
9 & 1.53 & 0.42 & 0.123 & 0.044 & 8.0 & - & - & 2216 \\
10 & 0.41 & 0.11 & 0.095 & 0.026 & 23.2 & 3.16 & 0.05 & 3750 \\
11 & 0.27 & 0.07 & 0.108 & 0.030 & 40.1 & - & - & 3250 \\
Mean & $\mathbf{4 . 0 8}$ & $\mathbf{1 . 1 2}$ & $\mathbf{0 . 3 6 0}$ & $\mathbf{0 . 0 9 9}$ & $\mathbf{1 9 . 2}$ & $\mathbf{4 . 0 1}$ & $\mathbf{0 . 4 0}$ & $\mathbf{1 6 9 2}$ \\
SD & $\mathbf{3 . 7 4}$ & $\mathbf{1 . 0 3}$ & $\mathbf{0 . 3 2 1}$ & $\mathbf{0 . 0 8 8}$ & $\mathbf{2 1 . 6}$ & $\mathbf{1 . 3 6}$ & $\mathbf{0 . 2 4}$ & $\mathbf{1 1 5 1}$ \\
\hline
\end{tabular}

Note: All concentrations were measured on freeze-dried powder (dw) and the Hg concentrations converted on a wet weight basis (dw).

Marlin contains $72.53 \pm 1.72 \%$ of water $(n=13)$, which gives a conversion factor of 0.275 between dry and wet weights. All calculated results (ratio, percentages, mean, SD) are based on unrounded raw data, taking molar masses of $78.96 \mathrm{~g} / \mathrm{mol}$ for Se and $200.59 \mathrm{~g} / \mathrm{mol}$ for $\mathrm{Hg}$. PTWI values of fish specimens 2, 5, 6, 7, and 10 were calculated by assuming that inorganic $\mathrm{Hg}$ is speciated as $\mathrm{Hg}(\mathrm{Sec})_{4}$ and $\mathrm{HgSe}$ only (i.e., no $\left.\mathrm{Hg}(\mathrm{Cys})_{2}\right)$. 

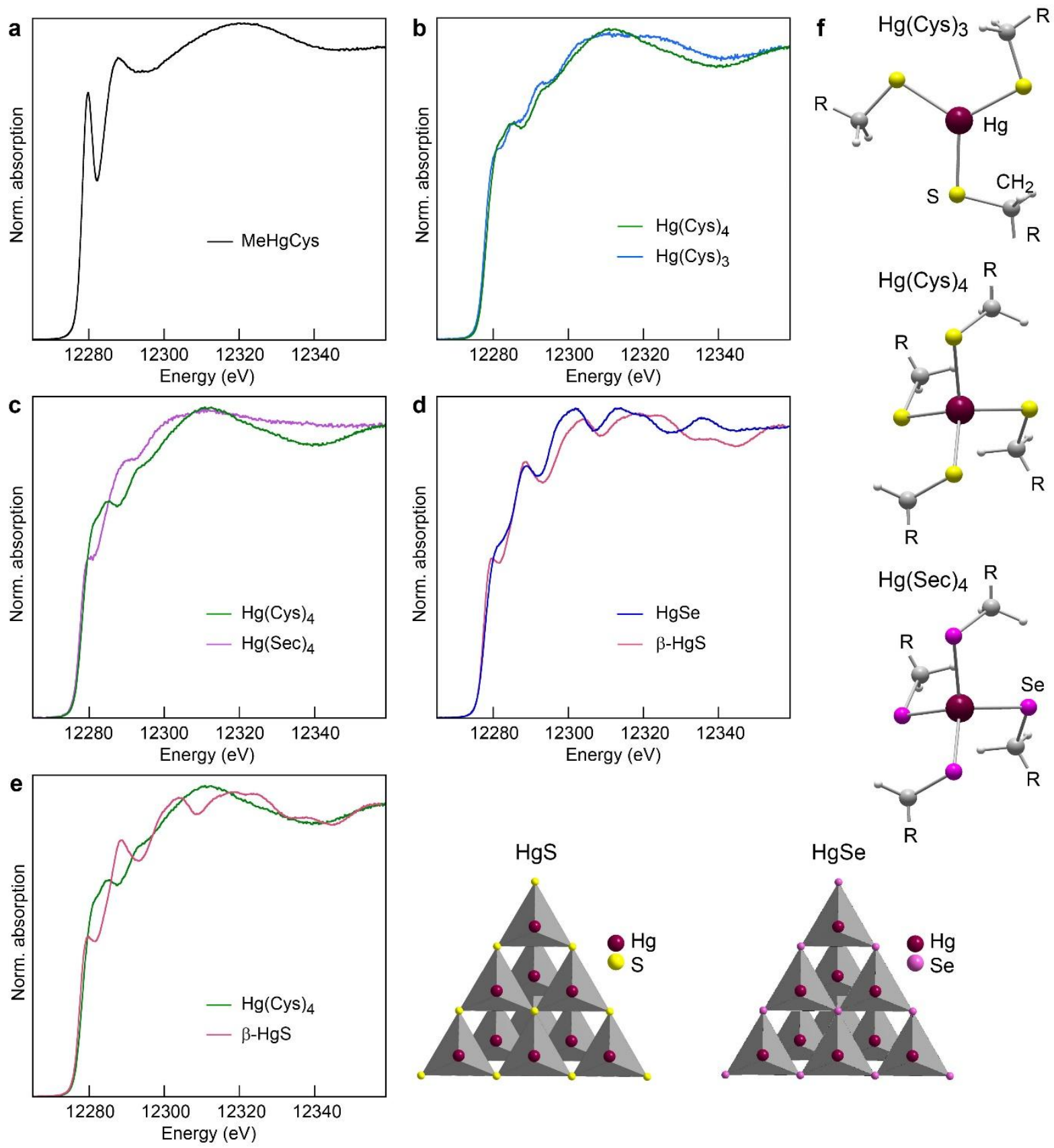

Figure S1. Sensitivity of $\mathrm{Hg} \mathrm{L}_{3}$-edge HR-XANES spectroscopy to $\mathrm{Hg}$ coordination. (a) $\mathrm{Hg}$ linearly coordinated to one methyl group and one cysteinate anion ( $\mathrm{MeHgCys}$ complex). The digonal coordination of $\mathrm{Hg}$ gives a sharp absorption line in the near-edge region (i.e., rising part of the absorption spectrum). The spectrum is from a feather of giant southern petrel ${ }^{1}$. (b) $\mathrm{Hg}$ three-coordinated $\left(\mathrm{Hg}(\mathrm{D}-\mathrm{Pen})_{3}{ }^{2,3}\right)$ and four-coordinated $\left(\mathrm{Hg}(\mathrm{Cys})_{4}{ }^{3,4}\right)$ to cysteinate anions. The energy of the trailing edge after the edge maximum depends on the $\mathrm{Hg}-\mathrm{S}$ distance, it is shifted to lower energy in $\mathrm{Hg}(\mathrm{Cys})_{4}$ which has a bond length of $\sim 2.55 \AA$, $\sim 0.1 \AA$ longer than in $\mathrm{Hg}(\mathrm{Cys})_{3}{ }^{5}$. (c) $\mathrm{Hg}$ four-coordinated to cysteinate (Cys) and selenocysteinate $\left(\operatorname{Sec}^{6}\right)$ anions. A higher absorption below the edge maximum and a flat absorption after the edge maximum distinguish the $\mathrm{Hg}$-Se bond from the $\mathrm{Hg}-\mathrm{S}$ bond. (d) $\mathrm{Hg}$ four-coordinated to sulfide anions in $\beta-\mathrm{HgS}$ and to 
selenide anions in HgSe. The two spectra are similar, because the two mineral structures are isomorphic. The absorption oscillations in the top-edge region are displaced to lower energy in $\mathrm{HgSe}$ as the $\mathrm{Hg}$-Se bonds are longer $\left(2.63 \AA^{7}\right.$ ) than the $\mathrm{Hg}-\mathrm{S}$ bonds $\left(2.53 \AA^{8}\right.$ ). (e) $\mathrm{Hg}$ fourcoordinated to $\mathrm{S}$ in $\mathrm{Hg}(\mathrm{Cys})_{4}$ and $\beta-\mathrm{HgS}$. The $\beta-\mathrm{HgS}$ trace oscillates on both sides of the $\mathrm{Hg}(\mathrm{Cys})_{4}$ trace, a result of the crystalline structure of $\beta-\mathrm{HgS}$ with $\mathrm{Hg}-\mathrm{Hg}$ pairs not existing in the $\mathrm{Hg}(\mathrm{Cys})_{4}$ complex. This observation holds for the comparison of $\mathrm{HgSe}$ and $\mathrm{Hg}(\mathrm{Sec})_{4}$ in Fig. $2 \mathrm{~d}$. (f) Bonding structure of $\mathrm{Hg}$ in $\mathrm{Hg}(\mathrm{Cys})_{3}, \mathrm{Hg}(\mathrm{Cys})_{4}$, and $\mathrm{Hg}(\mathrm{Sec})_{4}$ complexes, and in portions of the $\beta-\mathrm{HgS}$ and $\mathrm{HgSe}$ structures. Dark red, purple, yellow, gray, and light gray spheres represent $\mathrm{Hg}$, Se, S, C, and $\mathrm{H}$, respectively.

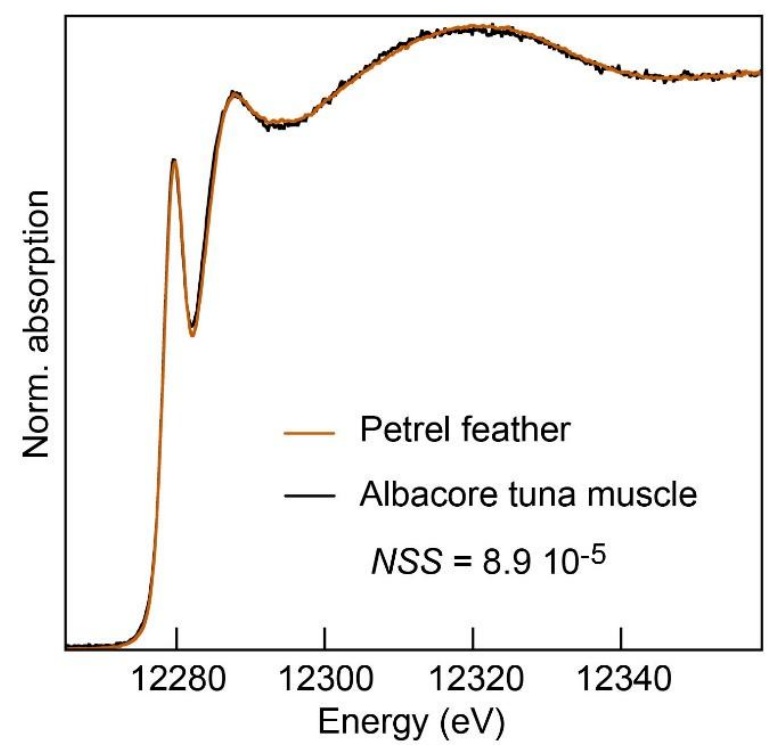

Figure S2. HR-XANES spectra of the muscle tissue from albacore tuna and feather from giant southern petrel. $100 \pm 5 \%$ of $\mathrm{Hg}$ is methylated in the two tissues ${ }^{1}$, in contrast to merlin muscle in which it is almost completely (>95\%) demethylated (Fig. 2b).

\section{Supplementary references}

(1) Manceau, A.; Gaillot, A. C.; Glatzel, P.; Cherel, Y.; Bustamante, P. In vivo formation of HgSe nanoparticles and Hg-tetraselenolate complex from methylmercury in seabird Implications for the Hg-Se antagonism. Environ. Sci. Technol. 2021, 55, 1515-1526.

(2) Leung, B. O.; Jalilehvand, F.; Mah, V. Mercury(II) penicillamine complex formation in alkaline aqueous solution. Dalton Trans. 2007, 4666-4674.

(3) Manceau, A.; Bustamante, P.; Haouz, A.; Bourdineaud, J. P.; Gonzalez-Rey, M.; Geertsen, V.; Barruet, E.; Rovezzi, M.; Glatzel, P.; Pin, S. Mercury(II) binding to metallothionein in Mytilus edulis revealed by high energy-resolution XANES spectroscopy. Chem-Eur J. 2019, 25, 997-1009. 
(4) Jalilehvand, F.; Leung, B. O.; Izadifard, M.; Damian, E. Mercury(II) cysteine complexes in alkaline aqueous solution. Inorg. Chem. 2006, 45, 66-73.

(5) Manceau, A.; Nagy, K. L. Relationships between $\mathrm{Hg}(\mathrm{II})-\mathrm{S}$ bond distance and $\mathrm{Hg}(\mathrm{II})$ coordination in thiolates. Dalton Trans. 2008, 11, 1421-1425.

(6) Manceau, A.; Bourdineaud, J. P.; Oliveira, R. B.; Sarrazin, S. L. F.; Krabbenhoft, D. P.; Eagles-Smith, C. A.; Ackerman, J. T.; Stewart, A. R.; Ward-Deitrich, C.; Busto, M. E. D.; Goenaga-Infante, H.; Wack, A.; Retegan, M.; Detlefs, B.; Glatzel, P.; Bustamante, P.; Nagy, K. L.; Poulin, B. A. Demethylation of methylmercury in bird, fish, and earthworm. Environ. Sci. Technol. 2021, 55, 1527-1534

(7) Earley, J. W. Description and synthesis of the selenide minerals. Am. Miner. 1950, 35, 337364.

(8) Rodic, D.; Spasojevic, V.; Bajorek, A.; Onnerud, P. Similarity of structure properties of $\mathrm{Hg}_{1-}$ ${ }_{x} \mathrm{Mn}_{\mathrm{x}} \mathrm{S}$ and $\mathrm{Cd}_{1-\mathrm{x}} \mathrm{Mn}_{\mathrm{x}} \mathrm{S}$ (structure properties of $\mathrm{HgMnS}$ and $\mathrm{CdMnS}$ ). J. Mag. Mag. Mater. 1996, $152,159-164$. 